\title{
Bentuk Perilaku Agresif Anak Setelah Menonton Televisi pada Kelompok B di Taman Kanak-Kanak
}

\author{
Nisaaul Hanifah ${ }^{\otimes_{1}}$, Rakimahwati ${ }^{2}$ \\ Pendidikan Anak Usia Dini, Universitas Negeri Padang, Indonesia(1) \\ DOI: $10.31004 /$ obsesi.v6i3.375
}

\begin{abstract}
Abstrak
Perkembangan prilaku anak usia dini merupakan salah satu aspek yang harus dicapai oleh anak dalam perkembangannya. Tujuan penelitian ini adalah untuk mengetahui bentuk-bentuk perilaku agresif anak yang muncul setelah menonton televisi, untuk mengetahui tayangan televisi yang disaksikan anak agresif, untuk mengetahui peran dan tanggapan orang tua terhadap anak agresif ketika menonton televisi di rumah. Jenis penelitian ini adalah penelitian lapangan (Field research) yang bersifat kualitatif. Penelitian yang dilakukan melibatkan subjek sebanyak 12 orang yaitu terdiri dari lima orang tua anak, dua anggota keluarga anak, dua guru kelas dan tiga orang anak yang berperilaku agresif. Pada penelitian ini menggunakan teknik wawancara, observasi dan dokumentasi. Dokumentasi berupa foto kegiatan peneliti dalam mewawancara dan mengobservasi anak berperilaku agresif. Instrumen utama adalah peneliti sendiri yang dibantu dengan wawancara dan observasi.
\end{abstract}

Kata Kunci: perilaku agresif; menonton televisi; anak usia dini

\begin{abstract}
The development of early childhood behavior is one aspect that must be achieved by children in their development. The purpose of this study was to determine the forms of aggressive behavior of children that appear after watching television, to determine television shows witnessed by aggressive children, to determine the role and responses of parents to aggressive children when watching television at home. This type of research is a qualitative field research. The research involved 12 subjects, consisting of five children's parents, two children's family members, two classroom teachers and three children who behaved aggressively. In this study using interview techniques, observation and documentation. Documentation in the form of photos of researchers' activities in interviewing and observing children behaving aggressively. The main instrument is the researcher himself who is assisted by interviews and observations.
\end{abstract}

Keywords: aggressive behavior; watching television

Copyright (c) 2021 Nisaul Hanifah, Rakimahwati

$\triangle$ Corresponding author:

Email Address : Nisaulh01@gmail.com ( Padang, Sumatera Barat, Indonesia )

Received 2 March 2021, Accepted 23 August 2021, Published 8 September 2021 


\section{PENDAHULUAN}

Tahapan anak usia dini merupakan periode paling penting pada masa kehidupan manusia, pada tahapan ini terdapat potensi yang baik untuk pertumbuhan dan perkembangan anak (Suyadi, 2015). Dilanjutkan oleh Khaironi (2018) pengetahuan perkembangan anak menjadi modal orang dewasa untuk menyiapkan berbagai stimulus, strategi dan rencana. Namun, pada beberapa konsep anak usia dini berada pada masa kritis, yaitu masa keemasan yang tidak akan dapat diulang kembali pada masa-masa berikutnya, Pada rentang usia 0-6 tahun, perkembangan anak mulai pesat, dari perkembangan fisik, intelektual, bahasa, sosial, emosional, moral, seni dan kreatifitas (Ulfah, 2019). Perkembangan dan pertumbuhan pada anak usia dini harus mendapat stimulus yang baik sehingga tidak adanya permasalahan yang terjadi pada anak, dilihat dari peran orang tua terhadap pemberian stimulus pada anak sudah sangat jarang di dapatkan akibat perekonomian, tuntutan kerja dan permasalahan lainnya yang berakibat fatal terhadap anak, misalnya pada permasalahan emosional anak.

Menurut Bridges Agustin (2011) proses perkembangan dan diferensiasi emosional pada anak sebagai berikut: Pada usia 2 tahun, kenikmatan dan keasyikan didiferensiasikan dengan kesenangan. Mulai usia 5 tahun, ketidaksenangan dan keasyikan didiferensiasikan ke dalam rasa malu, cemas dan kecewa (Nasution, 2020). Para ahli sering mengatakan bahwa generasi sekarang cenderung mulai mengalami gangguan emosi seperti pemurung, kesepian, kurang sopan dan agresif. Sedangkan menurut Masitoh (2015) "Agresif merupakan keinginan untuk menyerang kepada sesuatu yang dipandang sebagai suatu hal atau situasi yang mengecewakan, menghalangi atau menghambat". Dalam agresif didapatkan juga istilah lainnya yang sebutkan oleh Busman dan Bartholow (Abdul, 2013) yaitu "Kekerasan atau violence Kekerasan sebetulnya dapat dinyatakan sebagai agresi juga tetapi dalam konteks kekerasan intensitas dan efeknya lebih besar dari agresi “. Bentuk-bentuk perilaku anak yang mengarah ke perilaku agresif seperti yang dikemukakan oleh Wiyani (2014) terdapat dua bentuk perilaku agresif yaitu agresif secara fisik misalnya memukul, menendang, mencubit, menampar, menggigit, mendorong sampai jatuh, dll dan agresif secara verbal misalnya hinaan, omelan, makian, cercaan, ejekan, meneriaki, membentak.

Salah satu penyebab perilaku agresi muncul disebabkan oleh tayangan televisi yang disaksikan anak ketika menyaksikan film terkhusus kartun. Menurut Hurlock (Mayrizki, 2013) "Anak-anak prasekolah menyukai dramatisasi yang melibatkan hewan dan orang yang dikenal, musik, kartun, komedi sederhana. Anak kelas satu dan dua menyukai pertunjukan boneka, film koboi, misteri, humor, suasana kehidupan keluarga dan acara kuis berhadiah. Anak kelas tiga dan empat tertarik dengan acara yang imajinatif seperti tentang roket dan kendaraan luar angkasa, show, cerita misteri, detektif, drama, dan musik. Anak kelas lima dan enam tetap menyukai acara tersebut, tetapi mereka juga menyukai acara yang berkaitan dengan ilmu pengetahuan dan hasta karya. Cerita, komedi, kartun, dan musik disenangi anak di setiap tingkatan usia" (Hamzah et al., 2021). Tayangan kartun sekalipun dalam acara televise masih memiliki kandungan yang tidak seharusnya disaksikan anak. Dikuatkan oleh Bestbook (2013) "Terutama film-film kartun dari luar negeri karena terdapat perbedaan budaya".

Program acara televise menyajikan berbagai acara dan genre yang tidak semua cocok untuk anak. Lin dalam Sabardila et al. (2021) bahwa anak yang berlebihan menonton televisi dapat merusak perkembangan anak. Dilanjutkan oleh Rimm (2003) mengatakan bahwa anak "Cenderung meniru perilaku yang agresif, seperti dalam perselisihan kecil yang terjadi pada anak, anak yang sering menonton televisi akan menyelesaikan perselisihannya dengan menendang dan memukul dari pada berbicara". Anak adalah manusia kecil yang memiliki sifat peniru yang meniru apasaja yang berada di sekitarnya mulai dari peniruan perilaku baik dan perilaku buruk. Tandry (2016) menjelaskan dalam "Sebuah penelitian di Amerika Serikat menunjukan bahwa terlalu sering menonton tayangan yang bernuansa kekerasan membuat anak beranggapan bahwa kekerasan adalah hal yang wajar dalam kehidupan sehari-hari. Hal 
ini memicu anak untuk menjadi lebih agresif dan membuatnya memiliki kecenderungan untuk memecahkan persoalan dengan menggunakan kekerasan terhadap orang lain".

Musbikin (2007) berpendapat bahwa "Aneka tayangan media audiovisual di mana sekarang hampir setiap menit disajikan adegan berbau agresif juga mempunyai andil menambah tingkat agresivitas pada anak-anak. Tayangan televisi yang disuguhkan ke anak pada jam istirahat anak di rumah setelah pulang sekolah kebanyakan terdiri dari tayangan sinetron dan sinema seperti tayangan sinetron Manusia Harimau, Anak Langit, Kisah Nyata. Dalam tayangan tersebut diperlihatkan bagaimana cara berkelahi, baku hantam, dan kekerasan baik fisik maupun verbal. Contoh lain yaitu terdapat juga dalam tayangan kartun merupakan tayangan imajinasi yang di sukai anak seperti tayangan kartun Doraemon, dalam kartun ini anak diajak berfantasi tentang boneka yang memiliki kantong hebat yang anak inginkan, terbang, menyeberangi dunia lain, mengalahkan musuh dengan tangan ajaib, mengusili teman sekelas.

Menurut Mursy (2001) "Satu hal yang tidak dapat diragukan lagi bahwa sebagian besar acara-acara televisi lebih menonjolkan unsur-unsur sadisme sehingga berdampak negatif terhadap pemirsanya. Hal ini dapat menguatkan suatu anggapan bahwa perilaku kekerasan dan kekejaman yang pertama kali dilihat oleh anak kecil adalah berasal dari siaran televisi, apalagi bila dikaitkan dengan intesitas mereka dalam menyaksikan televisi semakin meningkat saat menjelang usia remaja". Acara-acara yang ditayangkan televisi dalam rumah yang memiliki unsur sadisme, kekerasan yang ditayangkan mempunyai dampak yang buruk terhadap penontonya, terutama pada anak-anak. Perilaku buruk yang anak miliki seperti perilaku kekerasan dan kekejaman berasal dari tayangan televisi yang ia saksikan dan dapat menjadikan anak-anak menjadi agresif (Silva et al., 2021). Dilanjutkan oleh (Raihan, Fajri., Rachman, f., Gita Saputra, I., dan Iqbal Afghan (2020) mengatakan bahwa perkembangan televisi membuktikan bahwa dengan sifat audiovisual yang dimilikinya, menjadikan televisi sangat pragmatic sehingga mudah mempengaruhi penonton dalam hal sikap, tingkah laku, dan pola pikir, anak akan meniru orang yang dikaguminya Santrok dalam Siahaan et al. (2021).

Besarnya pengaruh televisi terhadap anak mulai dari pengaruh baik dan pengaruh buruk dapat ditentukan oleh jumlah bimbingan dan pengawasan orang tua terhadap anak yang menonton. Bimbingan yang orang tua berikan kepada anak akan dapat menambah wawasan serta dapat mengurangi perilaku agresif anak.

\section{METODOLOGI}

Jenis penelitian ini adalah penelitian lapangan (Field research) yang bersifat kualitatif. Jenis pendekatan penelitian kualitatif yang digunakan adalah pendekatan deskriptif kualitatif. Penelitian yang dilakukan melibatkan subjek sebanyak 12 orang yaitu terdiri dari lima orang tua anak, dua anggota keluarga anak, dua guru kelas dan tiga orang anak yang bersekolah di Taman Kanak-Kanak Kasih Ibu. Pada penelitian ini mengunakan teknik wawancara, observasi dan dokumentasi. Dokumentasi berupa foto kegiatan peneliti dalam mewawancara dan mengobservasi anak berperilaku agresif. Instrumen utama adalah peneliti sendiri yang dibantu dengan wawancara dan observasi. Penyajian data didapat dari hasil wawancara dari guru orang tua dan anggota keluarga, dimana data yang disajikan bermaksud untuk mendapat jawaban atas permasalahan yang ada. Dalam penelitian kualitatif ada banyak analisis data yang digunakan. Uji keabsahan data data pada penelitian kualitatif hanya ditekankan pada uji validitas dan reabilitas, karena dalam penelitian kualitatif kriteria utama pada data teknik pemeriksaan keabsaan data yang digunakan dalam penelitian menggunakan teknik triangulasi (gabungan). Triangulasi data dari berbagai sumber dengan berbagai cara, dan berbagai waktu.

Triangulasi yang digunakan dalam penelitian ini Dijabarkan oleh Sugiyono (2011) Sebagai teknik pengumpulan data yang bersifat menggabungkan dari berbagai teknik pengumpulan data dan sumber data dengan berbagai cara dan berbagai waktu yang telah 
ada. Selanjutnya Sugiyono (2011) membagi 3 macam Triangulasi: (1) Triangulasi sumber untuk menguji kreadibilitas data tentang perilaku murid, maka pengumpulan dan pengujian data yang telah diperoleh dapat dilakukan ke guru, teman murid yang bersangkutan dan orang tuanya. Data yang telah dianalisis oleh peneliti akan menghasilkan suatu kesimpulan selanjutnya diminta kesepakatan dari tiga sumber tersebut. (2) Triangulasi teknik untuk menguji kredibilitas data dilakukan dengan cara mengecek kepada sumber yang sama dengan teknik yang berbeda, misalnya data diperoleh dengan wawancara, lalu dicek dengan observasi, dokumentasi. Bila dengan tiga teknik pengujian kredibilitas data tersebut, menghasilkan data yang berbeda-beda, maka peneliti melakukan diskusi lebih lanjut kepada sumber data yang bersangkutan atau yang lain, untuk memastikan data mana yang dianggap benar. (3) Triangulasi waktu data yang dikumpulkan dengan teknik wawancara di pagi hari saat narasumber masih segar, belum banyak masalah akan memberikan data yang lebih valid sehingga lebih kredibel. Untuk itu dalam rangka pengujian kreadibilitas data dapat dilakukan dengan cara melakukan pengecekan dengan wawancara, observasi atau teknik lain dalam waktu atau situasi yang berbeda, maka dilakukan secara berulang-ulang sehingga sampai ditemukan kepastian datanya.

\section{HASIL DAN PEMBAHASAN}

\section{Hasil Penelitian}

Bentuk bentuk permasalahan perilaku agresif yang terjadi pada anak usia dini di taman kanak-kanak disebabkan dari tontonan yang ia saksikan ketika di rumah. televisi memang tidak serta merta menjadi satu-satunya hal yang dapat menimbulkan perilaku agresif, namun juga tergantung pada kebiasaan anak dalam melihat tayangan televise. Pengaruh tayangan televisi yang buruk dapat merusak perilaku anak, hal ini merupakan permasalahan dapat menyebabkan terganggunya pembelajaran dalam sebuah pendidikan.

Berdasarkan hasil dari penelitian yang dilakukan di TK Islam Harapan Ibu Batusangkar tentang bentuk perilaku agresif anak setelah menonton tayangan televisi di kelompok B, didapatkan bahwa Perilaku agresif yang ada pada anak dapat mencelakai anak lain seperti cedera, adanya perkelahian, dan adanya ketidak nyamanan anak, bentuk perilaku yang anak keluarkan ada dua yaitu secara fisik dan verbal. Bentuk perilaku yang dimunculkan anak secara fisik berdasarkan penelitian adalah memukul, menendang, mengigit, mencubit, mendorong, bertengkar dan menendang benda, selanjutnya perilaku secara verbal yang dimunculkan anak perilaku agresif adalah mencibir, mencemooh, mengganti nama teman dan mengolok-olok.

Adapun hasil penelitian yang diperoleh dari bentuk perilaku agresif anak setelah menonton televisi, hasil yang diperoleh dari berbagai sumber wawancara dan pengamatan di sekolah, bentuk perilaku agresif secara fisik anak BM, GN dan IH yang muncul berdasarkan keinginan diri. Bentuk perilaku agresif secara fisik merupakan tindakan yang berkenaan dengan anggota tubuh yaitu menendang teman, memukul, mencubit, meninju punggung teman, menendang sepatu teman, mengigit dan berkelahi, sedangkan perilaku agresif secara verbal anak seperti mencibir, merubah nama teman dan mengejek dalam bentuk ucapan tantangan.

Hasil penelitian selanjutnya dilihat dari tayangan televisi yang anak saksikan anak BM, GN dan IH. Intensitas waktu anak menonton adalah 2-3 jam dalam sehari dan itu dilakukan rutin pada setiap harinya. Berikut kesimpulan kegiatan menonton televisi yang biasa anak lakukan adalah pagi 06.00-07.00 sebelum berangkat sekolah, pulang sekolah 11.00-13,00 dan sore menjelang malam pada jam 19.00-20.00, karena pada jam-jam segitu banyak tayangan favorit yang disukai anak terlebih yaitu film kartun.Program tayangan yang sering dilihat dan disukai anak adalah tayangan animasi kartun dan sinetron. Bentuk peniruan anak BM, GN, IH setelah menonton televisi berdasarkan observasi dan wawancara dari tayangan televisi yang disaksikan BM adalah tayangan Boboi Boy perilakunya seperti menedang, berjungkir balik, dan melompati kursi, GN menyukai tayangan Sinetron Anak Langit, Dinasaurus dan 
Otobot mengaum seperti harimau secara tiba-tiba, meloncat seperti dinosaurus dari meja satu kemeja lain, dan untk anak IH menyukai jagoan Utraman perilaku yang IH perlihatkan adalah menjatuhan diri, berguling dan berlari kencang.

\section{Pembahasan}

Banyak pandangan dan pendapat bahwa anak-anak sangat rentan untuk mendapat pengaruh televisi, berbagai dampak yang sering dianggap muncul adalah pada pengaruh buruk, seperti perilaku agresif yang terdiri dari dua bentuk yaitu perilaku agresif secara fisik dan perilaku agresif secara verbal Nurwita (2019). Anak banyak belajar dan meniru dari apa yang mereka saksikan secara langsung. Dimana Hal ini menguatkan pendapat Arifin, Bambang (2015) jika anak menyaksikan adegan kekerasan maka akan terjadinya proses belajar dari model yang melakukan kekerasan sehingga akan memunculkan perilaku agresi. Bentuk perilaku yang dimunculkan anak secara fisik berdasarkan penelitian adalah memukul, menendang, mengigit, mencubit, mendorong, bertengkar dan menendang benda, selanjutnya perilaku secara verbal yang dimunculkan anak perilaku agresif adalah mencibir, mencemooh, mengganti nama teman dan mengolok-olok.

Menurut Hasan dalam Wiyani (2014) ia mengatakan bahwa ketika anak berumur tiga hingga enam tahun, selain memukul dan menendang ia akan menampakkan perilaku agresif yang bersifat verbal dan memfokuskan perilaku agresifnya pada kebendaan. Selain itu (Hildayani, 2015) juga menambahkan bahwa ketika anak memasuki usia 3-7 tahun, perilaku agresif menjadi bagian dari tahap perkembangan mereka dan sering kali menimbulkan masalah, tidak hanya dirumah tetapi juga di sekolah.

Menurut KPAI.go.id mengatakan bahwa "Kejadian Prilaku Agresif pada anak di Indonesia meningkat pada setiap tahunnya sekitar 1000 kasus setiap tahunnya. Pada tahun 2011 terjadi sebanyak 2178 kasus, pada tahun 2012 ada 3512 kasus, di tahun 2013 ada 4311 kasus dan di tahun 2014 terdapat 5066 kasus. 78,3\% dari kasus tersebut pelakunya adalah anak-anak sendiri, dan 87,6\% kasusnya terjadi pada lingkungan pendidikan. Mirisnya banyak kasus kekerasan dalam berprilaku agresi dilakukan oleh anak-anak dan terjadi di lingkung sekolah yang berdampak bukan pada luka fisik tetapi juga dapat melukai psikis anak yang menjadi korban" (Fitriyah, 2019)

Agresi pada anak juga dapat terjadi akibat dipengaruhi media massa yang berisi kekerasan (tayangan film) (Suprihatin, n.d.).Televisi banyak menimbulkan dampak dan sudah menjadi kebutuhan di masyarakat (Agustina, 2016). Intensitas menonton televisi dapat mempengaruhi perilaku anak baik di lingkungan sekolah maupun di rumah,. Waktu menonton anak yang dilakukan di rumah yaitu pada pagi hari sebelum pergi sekolah, pulang sekolah dan pada sore hari. Kegiatan rutin yang anak lakukan merupakan sarana hiburan dan teman bermain fantasi bagi anak karena 2 dari 3 anak yang diteliti orang tuanya memiliki kesibukan dalam pekerjaan sehingga, orang tua mengantisipasi dengan memberi televisi untuk anak.

Menurut Muzayyad Tamburaka (2013) sebuah penelitian menunjukan bahwa rata-rata anak Indonesia menonton TV sekitar 2,3,5 dalam sehari bahhkan penelitian YPMA menunjukan 4-6 jam perhari. Kondisi ini memungkinkan anak mengalami kecanduan dalam menonton dan banyak didapatkan tayang yang tidak baik ditonton anak. Anak-anak menyukai film fantasi, bahkan bentah dalam waktu lama melihat tayang televisi. Menurut (Tandry, 2016) terlalu banyak menonton televisi dapat membuat anak pasif dan tidak kreatif karena mereka hanya duduk di depan televisi sehingga memberikan efek "candu".

Intensitas waktu menonton anak akan lebih dipengaruhi dengan program tayangan yang anak saksikan karena dengan menyaksikan program tayangan televisi lebih besar peniruan anak atau daya fantasi anak terhadap yang anak saksikan. Pada usia perkembangan, anak memiliki ketertarikan pada film yang memiliki petualangan dan ketegangan seperti dalam film kartun". Temuan ini juga merespon teori yang di ungkapkan oleh Hurlock (Mayrizki, 2013) yang menyatakan bahwa "Anak-anak prasekolah menyukai dramatisasi 
yang melibatkan hewan dan orang yang dikenal, musik, kartun, komedi sederhana. Anak kelas satu dan dua menyukai pertunjukan boneka, film koboi, misteri, humor, suasana kehidupan keluarga dan acara kuis berhadiah. Anak kelas tiga dan empat tertarik dengan acara yang imajinatif seperti tentang roket dan kendaraan luar angkasa, show, cerita misteri, detektif, drama, dan musik. Anak kelas lima dan enam tetap menyukai acara tersebut, tetapi mereka juga menyukai acara yang berkaitan dengan ilmu pengetahuan dan hasta karya. Cerita, komedi, kartun, dan musik disenangi anak di setiap tingkatan usia"(Palupi \& Budiyanto, 2016). Indonesia juga berlomba dalam menghadirkan tayangan yang dapat menarik perhatian baik anak-anak atau orang dewasa. Rusman \& Yustiatie (2015) juga menambahkan bahwa program ini berbentuk program tayangan kartun dan animasi, dalam layar lebar televisi Indonesia pernah ditayangkan film Ice Age, Tarzan, Kungfu Panda, dan Transformers.

Program tayanga televisi yang disaksikan anak pulang sekolah pada jam 13.00 terdapat film animasi jagoan yang digemari anak melalui tayangan pahlawan kota dalam memberantas musuh, dalam tayang tersebut tokoh utama menyelamatkan kota mengunakan kekuatan dan dalam pertarungan yaitu film Tobot di RTV. Selanjutnya (Risti, 2019) tayangan sinetron yang disaksikan oleh anak pada malam hari seperti perkelahian antara geng, menampakkan permusuhan, dan saling mengejek. Film yang disaksikan dapat menjadi ajang peniruan bagi anak sesuai dengan pembelajaran sosial menurut Bandura (Tamburaka, 2013) bahwa kita belajar bukan saja dari pengalaman langsung, tetapi dari peniruan atau peneladanan. Perilaku merupakan hasil dari faktor kognitif dan lingkungan. bentuk peniruan yang dilakukan anak dari tayangan televisi adalah mengeluarkan jurus seperti tokoh film idolanya dalam tayangan kartun Boboi Boy yaitu, memukul mengunakan bantal guling, menedang, berjungkir balik, dan melompati kursi, anak selanjutnya dalam tayangan sinetron Anak Langit serta kartun Tobot perilakunya adalah mengaum seperti harimau secara tibatiba, meloncat seperti dinosaurus dari meja satu kemeja lain, dan anak terakhir menyaksikan tayangan Utraman sehingga anak mengeluarkan perilaku seperti menjatuhan diri, berguling dan berlari kencang, seakan-akan anak memiliki kekuatan yang dimiliki oleh tokoh film idola kartunnya. Hal ini menguatkan teori Musbikin (2007) televisi sering juga menayangkan model yang cepat ditiru oleh anak. Bila anak sering menonton pertunjukan yang penuh dengan adegan kekerasan, ia akan meniru, peniruan yang dilakukan anak terjadi sesudah menonton televisi dirumah beberapa saat setelah menonton maupun sewaktu iklan berlangsung.

\section{SIMPULAN}

Bentuk perilaku agresif anak yang muncul adalah perilaku agresif secara fisik dan agresif verbal. Intensitas waktu yang digunakan anak dalam menonton televisi adalah sekitar 2-3 jam dalam perhari. Program menonton televisi yang sering disaksikan anak adalah jenis tayangan kartun dan tayangan sinetron perkelahian. Dalam tayangan kartun yang disukai anak adalah tayangan fantasi kartun yang mengambarkan perkelahian, seperti tayangan Boboi Boy perilakunya seperti menedang, berjungkir balik, dan melompati kursi, tayangan Otobot, Sinetron Anak Langit. Bentuk prilaku agresif anak di TK Harapan Ibu setelah menonton televisi adalah Prilaku Agresif secara fisik dan verbal.

\section{UCAPAN TERIMAKASIH}

Ucapan terimakasih penulis sampaikan kepada Universitas Islam Negeri Batusangkar yang telah memberikan fasilitas dalam proses penelitian sehingga dapat tersusun artikel ini hingga dapat dipublikasikan. Keluarga besar TK Islam Harapan Ibu sebagai tempat pelaksanaan penelitian sehingga memperoleh data yang dibutuhkan, tim pengumpul data, dan tim penerjemah abstrak. 


\section{DAFTAR PUSTAKA}

Abdul, A. R. (2013). Psikologi Sosial. PT Raja Grafindo Persada.

Agustina, D. (2016). Pengaruh Intensitas Menonton Televisi Terhada Kedisiplinan Anak Dalam Membagi Waktu Belajar Di MIN 2 Model Samarinda. Jurnal Ilmu Komunikasi, 4(3), 305-319. $\quad$ https://ejournal.ilkom.fisip-unmul.ac.id/site/wpcontent/uploads/2016/08/Jurnal Dewi (08-24-16-04-13-50).pdf

Arifin, Bambang, S. (2015). Psikologi Sosial. CV Pustaka Setia.

Bestbook. (2013). Friendly \& firm parenting-Mendisiplinkan Anak Secara Bersahabat dan Tegas. G-Media.

Fitriyah, F. K. (2019). Pengaruh Perilaku Agresif Pada Anak Usia Dini Terhadap Kecemasan Dan Empati. Education and Human Development Journal, 4(1), 95-102. https://doi.org/10.33086/ehdj.v4i1.1088

Hamzah, N. H., Khomaeny, E. F. F., \& Ulfa, M. (2021). Tontonan anak di Televisi: Paradoks dan Kontestasi Nilai Tontonan Anak di Media Televisi Nasional. Jurnal Obsesi : Jurnal Pendidikan Anak Usia Dini, 5(2), 1883-1893. https://doi.org/10.31004/obsesi.v5i2.713

Hildayani, R. (2015). Materi Pokok Penanganan Anak Berkelainan. Universitas Terbuka Press. Juntika, A., \& Agustin, M. (2013). Dinamika Perkembangan Anak dan Remaja Tinjauan Psikologi. In Pendidikan dan Bimbingan Bandung PT Refika .... Refika Adiutama.

Khaironi, M. (2018). Perkembangan anak usia dini. Jurnal Golden Age Hamzanwadi University. https:// doi.org/10.29408/goldenage.v2i01.739

Masitoh, L. (2015). Pengaruh tayangan televisi terhapa perilaku agesif anak usia 4-6 tahun di taman kanak-kanak kecamatan jati kabupaten kudus. EduTech, 2(1).

Mayrizki, Y. (2013). Pengaruh Media Televisi Terhadap Perilaku Anak. Fakultas Ilmu Pendidikan (PGRA). Universitas Negeri Semarang.

Mursy, S. (2001). Seni Mendidik Anak. Pustaka Alkausar.

Musbikin, I. (2007). Mendidik Anak Nakal. Mitra Pustaka.

Nasution, N. K. (2020). Perkembangan Anak Usia Dini (AUD) di TK Aisyiyah: Problematika dan Solusi. Jurnal Penelitian Keislaman, 15(2), 130-143. https://doi.org/10.20414/jpk.v15i2.1425

Nurwita, S. (2019). Analisis Nilai-Nilai Agama dan Moral Anak Usia Dini dalam Tayangan Film Kartun Upin dan Ipin. Jurnal Obsesi : Jurnal Pendidikan Anak Usia Dini, 3(2), 506. https://doi.org/10.31004/obsesi.v3i2.252

Palupi, T. N., \& Budiyanto, R. (2016). Pengaruh Intensitas Menonton Tayangan Sinetron Terhadap Perilaku Hedonisme Para Remaja. Jurnal Psikologi Pendidikan Dan Perkembangan SDM, 4(1). https://doi.org/10.25139/jkm.v1i2.460

Raihan, F., Rachman, F., Gita Saputra, I., \& Iqbal Afghan, M. (2020). Pengaruh Tayangan Kartun di TV Terhadap Kemampuan Bersosialisasi Anak. Communications, 2(1), 5166. https:// doi.org/10.21009/Communications.2.1.4

Risti, D. (2019). Pengaruh Sinetron Terhadap Perilaku Anak di Dalam Kehidupan Sehari-hari. Indonesian Journal of Primary Education, 3(2), 42-43.

Rusman, L., \& Yustiatie, U. (2015). Siaran televisi non-drama: kreatif, produksi, public relations, dan iklan. Kencana.

Sabardila, A., Markhamah, M., Arifin, Z., Kusmanto, H., Hidayah, L. N., Kurniasari, A. D., \& Saputro, D. (2021). Menakar Nilai Pendidikan Karakter Acara Televisi pada Anak Usia 6-8 Tahun. Jurnal Obsesi: Jurnal Pendidikan Anak Usia Dini, 6(1), 150-162. https://doi.org/10.31004/obsesi.v6i1.875

Siahaan, Y. E., Sutapa, P., \& Yus, A. (2020). Pengaruh Komunikasi Orangtua terhadap Perilaku Agresif verbal Anak Usia 5-6 Tahun. Jurnal Obsesi : Jurnal Pendidikan Anak Usia Dini, 5(2), 1472-1486. https:// doi.org/10.31004/obsesi.v5i2.890

Silva, lintang dian, Pranajaya, syatria adymas, \& Hadi, S. (2021). Imajinasi Tontonan Televisi Terhadap Tuntunan Diri Anak. Borneo Journal of Primary Education, I(1), 37-53. https://journal.iain-samarinda.ac.id/index.php/bjpe/article/view/3135/1239 
Sugiyono. (2011). Metode Penelitian Kuantitatif, Kualitatif dan R\&D. Alfabeta.

Suprihatin, T. (n.d.). Agresivitas Anak (Suatu Studi Kasus). Proyeksi, 6 (1)(1), 53-61.

Suyadi. (2015). Teori Pembelajaran Anak Usia Dini (N. Nur (ed.)). remaja rosdakarya.

Tamburaka, A. (2013). Literasi Media Cerdas Bermedia Khalayak Media Massa. PT Raja Grafindo Persada.

Tandry, N. (2016). Happy parenting with Novita Tandy. PT Buana Ilmu Populer.

Ulfah, M. (2019). Pendekatan Holistik Integratif Berbasis Penguatan Keluarga pada Pendidikan Anak Usia Dini Full Day. Jurnal Obsesi : Jurnal Pendidikan Anak Usia Dini, 4(1), 10. https:// doi.org/10.31004/obsesi.v4i1.255

Wiyani, N. A. (2014). Buku Ajar Penanganan Anak Usia Dini Berkebutuhan Khusus. Ar-Ruzz Media. 